\title{
Analysis E-procurement Implementation To Sourcing Performance (Case Study: PT Pembangunan Jaya Ancol,Tbk)
}

\author{
Abhibawa Tegar Kusuma ${ }^{1}$, Nofrisel ${ }^{2}$ \\ \{abhibawategarkusuma@yahoo.co.id ${ }^{1}$,nofrisel@yahoo.com² ${ }^{2}$, \\ student in MM Universitas Indonesia ${ }^{1}$, Lecturer in $\mathrm{MM} \mathrm{UI}^{2}$
}

\begin{abstract}
The focus of this study is to implement e-procurement on sourcing peformance at PT Pembangunan Jaya Ancol, Tbk. This research is a quantitative descriptive. Research was preceded by quantitative research, then to provide advice in form of practical implication, researcher used fishbone diagram tool. The result of this study shows these variabels are perceive benefit of e-procurement, perceived barriers to e-procurement implementation, and critical success factors in e-procurement give significant impact to several of perceived future of e-procurement. Therefore, each of these variable elements from perceive benefit of e-procurement and critical success factors in e-procurement must be present in a implementation of e-procurement. Also each of these variable perceived barriers to e-procurement implementation elements from must be avoid in a implementation of e-procurement.
\end{abstract}

Keywords: E-procurement, sourcing, procurement performance, procurement.

\section{Introduction}

[1]In a research, it was estimated that 50 to 70 percent of the potential costs incurred by manufacturing companies came from services purchased, whereas for the service industry, even half of their services came from services purchased from other companies. [2]Meanwhile, the cost of procurement of COGS (Cost of God Sold) reaches $50-70 \%$ for manufacturing companies, while for service companies it reaches $10-40 \%$. Therefore every company need to have a sourcing strategy.

Sourcing is the application of procurement strategies in the company. By implementing a sourcing strategy, the relationship with the vendor can be built as a strategic partner that is mutually beneficial and able to strengthen the business of both parties both from the company as a buyer and a vendor. One way to implement a sourcing strategy in utilizing the development of information technology is to implement e-procurement. PT Pembangunan Jaya Ancol, Tbk (PJA), has implemented the E-Procurement process since 2014. The implementation of e-procurement began with the launch of the e-procurement system as well as an e-procurement manual that contains SOPs about the rules and flow of the e-procurement process. The e-procurement used consists of several system modules such as vendor management, e-catalog, and e-auction.

Thus, researchers feel the need to conduct research on the implementation of eprocurement in PJA. This research is expected to provide insight into the implementation of eprocurement, as well as developing procurement at PJA. So this insight can improve the procurement performance of various companies and agencies in accordance with good corporate governance. 


\section{Literature Review}

\subsection{Sourcing}

[3]Procurement is included in the category of support activites in the company's value chain. Support activities function to make primary activities effective. Procurement is a process and series of activities to meet the supply of goods or services under the contract through a tender, direct selection and direct appointment process. One of the benefits of procurement is that it allows companies to focus on activities that present their core competencies. Thus, companies can make financing efficiency and be able to increase their competitive advantage.

Sourcing is another term for purchasing, a function of the company that is very important financially, but strategically is not the center of attention. [4]Strategic sourcing is a strategy to develop relationships with vendors to obtain goods and services in a way that helps achieve business needs. [5] defines sourcing as a strategic philosophy of choosing partners in a way that makes them an integral part of a company's procurement activities. Generally Request for Proposal (RFP) is usually used by companies to prepare detailed information packages that describe what will be purchased, which is then given to potential partners. The detailed information package in the RFP can be in the form and quantity of items purchased by the company and the administrative inclusion that partners must complete. [4]The partner then responds by giving a price quote along with the administration inclusion required in accordance with the RFP.

\subsection{E-procurement}

[6] E-procurement is the procurement of goods/services carried out using information technology and electronic transactions in accordance with statutory provisions. [7]Eprocurement offers better information and knowledge management and better supervision of supplier operations. [8][9]E-procurement offers better transparency in procurement and increases the speed, quantity, and quality of information processing. [10]In addition, eprocurement gives buyers more choices to choose suppliers with cheaper transactions. [11]Correct information, a smooth procurement process, and integrated supply chain are the benefits of adopting e-procurement. Therefore, e-procurement offers financially improved company performance and good governance.

Of the various benefits offered by e-procurement, it is necessary to implement eprocurement into the sourcing system. [12]A analyze for implementation of e-procurement by dividing it into 4 variables, they are perceived benefits of e-procurement, perceived barriers to e-procurement implementation, critical success factors in e-procurement, and perceived future organizational with e-procurement.

\subsection{Perceived benefit of e-procurement}

[12]Understanding the benefits of e-procurement shows managerial levels, technological expertise, concern for the existence of new technologies, including e-procurement. How much knowledge and understanding of the benefits of e-procurement affect the successful implementation of e-procurement. How much benefit is felt will affect management's expectations regarding the company's future performance with regard to e-procurement. 


\subsection{Perceived Barriers to E-procurement Implementation}

In adopting a new system, the company not only encountered benefits but also encountered obstacles that affected the implementation of the new system. [13]Identification obstacles in adopting e-procurement such as: security in transactions, lack of supplier solutions to eprocurement, high cost of technology, lack of legal framework, lack of knowledge about eprocurement, lack of business benefits identified, lack of trade standard data, and lack of business relationships with suppliers. [12]Barriers such as lack of capital, lack of expertise and technical skills, lack of technology and equipment, resistance to change, and lack of support from top management will hamper the process of adopting E-procurement or affect the performance of e-procurement after implementation.

\subsection{Critical Success Factors in E-procurement}

Success in implementing e-procurement is influenced by the application of important factors. These important factors take into account the characteristics, strategic approaches and operational policies in developing e-procurement implementation. [14]Several general factors that determine success in adopting e-procurement which consist of: proper measurement, stepby-step transformation, government support, operating systems, and maintenance mechanisms.

\subsection{Perceived Future Organizational with E-procurement}

[15]Strategic, tactical and operational benefits can be obtained from e-procurement. The extent to which the leadership of a company believes that e-procurement can have a positive impact on the company's performance in the future, will affect the tendency in implementing e-procurement. Therefore the importance of their awareness of the positive effects of eprocurement on company performance both in the short and long term, such as in production and service costs or the company's competitiveness, they must also recognize the role of eprocurement in strategic alliances with suppliers.

\section{Method}

This research began with quantitative research then the output results were analyzed using a fishbone diagram tool. From the determined research model, there are 3 independent variables and 1 dependent variable. Independent variables consist of perceived benefits of eprocurement, and critical success factors in e-procurement. While the dependent variable is Perceived future organization with e-procurement. Analysis of the effect of independent variables on the dependent variable using linear regression analysis partially or simultaneously. Regression analysis using statistical software tools namely SPSS volume 25.

Research respondents are PJA employees who occupy manager positions. The respondents were chosen because they represent 1 business unit each. The data collection period was conducted in the March 2020 period. Data collection was carried out by providing questionnaires that were shared through the Googleform platform. 


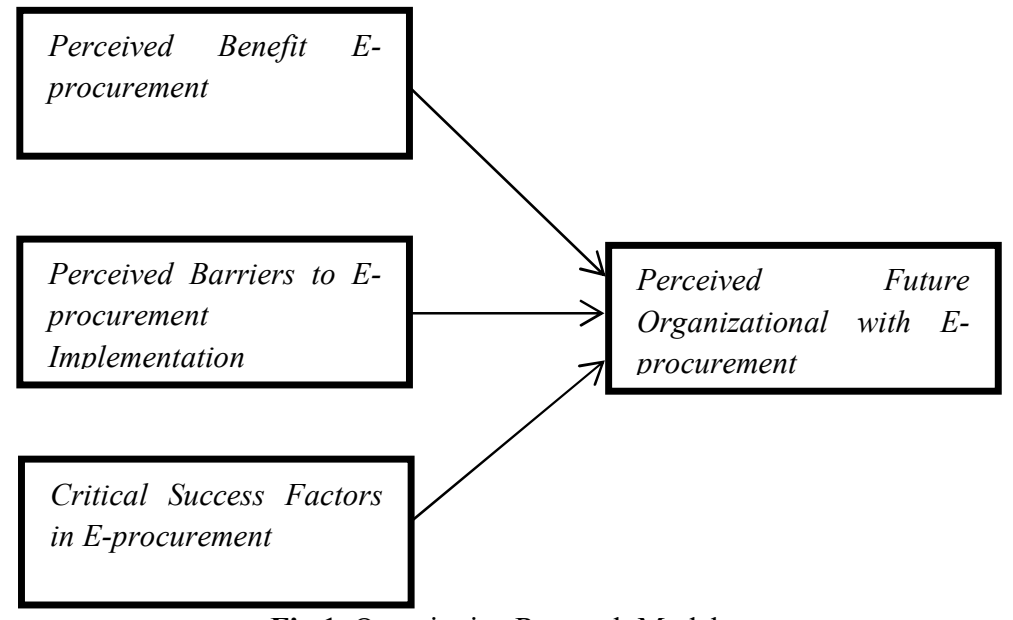

Fig.1. Quantitative Research Model

\section{Results And Discussion}

\subsection{Descriptive Analysis of the Perceived benefits of e-procurement}

For the perceived benefit e-procurement variable, there are 12 indicators of the questionnaire to determine the variable. Based on these results, it is illustrated that respondents tend to agree with the perceived benefit e-procurement variable which shows the benefits of eprocurement implementation.

Table 1. Perceived Benefit E-procurement

\begin{tabular}{lll}
\hline \multicolumn{2}{l}{ Perceived Benefit E-procurement } & Mean \\
\hline A1 & Better utilization on staff & 4.566667 \\
A2 & Efficient Increment & 4.066667 \\
A3 & Help to achieve SCM & 4.1 \\
A4 & Improved relationship with vendors & 4.066667 \\
A5 & Increased customer service level & 3.966667 \\
A6 & Increased customer satisfaction & 4 \\
A7 & Reduction in inventory levels & 3.8 \\
A8 & Reduction in non contractual buying & 4.166667 \\
A9 & Reduction in operational tasks & 3.7 \\
A10 & Reduction in processing time & 3.266667 \\
A11 & Reduction in transactional cost & 3.833333 \\
A12 & Support enviromental issues & 4 \\
\hline & Mean all & 3.961111 \\
\hline
\end{tabular}

\subsection{Descriptive Analysis of Perceived Barriers to E-procurement Implementation}

For perceived barriers e-procurement variables, there are 9 questionnaire indicators to determine these variables. Based on these results, it is illustrated that respondents tend to be 
neutral towards the perceived barriers to e-procurement implementation variables which indicate obstacles to e-procurement implementation.

Table 2. Perceived Barriers to E-procurement Implementation

\begin{tabular}{|c|c|c|}
\hline \multicolumn{2}{|r|}{ Perceived Barriers E-procurement Implementation } & \multirow{2}{*}{$\frac{\text { Mean }}{2.37}$} \\
\hline B1 & Fear to change into new system & \\
\hline B2 & Immaturity technology & 2.93 \\
\hline B3 & Incompatible with ERP system & 3.03 \\
\hline B4 & Insufficient financial support & 2.40 \\
\hline B5 & Lack of interoperability and standart with traditional communication & 2.80 \\
\hline B6 & Lack of skill and knowledge in e-procurement & 3.30 \\
\hline B7 & Lack of top management support and commitment & 2.20 \\
\hline B8 & Not the top initiative and priority of the company & 2.47 \\
\hline \multirow[t]{2}{*}{ B9 } & Security concerns & 2.40 \\
\hline & Mean all & 2.66 \\
\hline
\end{tabular}

\subsection{Descriptive Analysis of Critical Success Factors in E-procurement}

For the critical success factors variables in e-procurement, there are 11 questionnaire indicators to determine these variables. Based on these results, it is illustrated that respondents tend to be in agreement with the critical success factors variable in e-procurement which indicates the implementation of some of these success factors in the implementation of eprocurement in PJA.

Table 3. Perceived Critical Success Factors in E-procurement

\begin{tabular}{|c|c|c|}
\hline \multicolumn{2}{|r|}{ Critical Success Factors in E-procurement } & Mean \\
\hline $\mathrm{C} 1$ & Centralized control and management of e-procurement initiative & 4.17 \\
\hline $\mathrm{C} 2$ & Communication between participants & 3.97 \\
\hline $\mathrm{C} 3$ & Clear and achieveable implementation phase & 3.77 \\
\hline $\mathrm{C} 4$ & Clear accountability for buying in organizational structure & 4.07 \\
\hline $\mathrm{C} 5$ & Close collaboration with vendors & 3.83 \\
\hline C6 & Content management & 3.63 \\
\hline $\mathrm{C} 7$ & Information system specialist with internet skill & 3.90 \\
\hline $\mathrm{C} 8$ & Involvement of stakeholders & 3.87 \\
\hline C9 & Streamlined approvals and workflow & 3.73 \\
\hline $\mathrm{C} 10$ & The use of prototype & 3.97 \\
\hline $\mathrm{C} 11$ & Top management involvement and support & 4.13 \\
\hline & Mean all & 3.91 \\
\hline
\end{tabular}

\subsection{Descriptive Analysis of Perceived Future Organizational with E-procurement}

For perceived future organizational variables with e-procurement, there are 11 questionnaire indicators to determine these variables. This shows that respondents tend to agree that e-procurement implementation increases company profits. Based on these results, it is illustrated that respondents tend to be in agreement with the variable perceived future 
organization with e-procurement which indicates an organizational benefit in PJA in implementing e-procurement.

Table 4. Perceived Future Organizational with E-procurement

\begin{tabular}{llc}
\hline & Perceived Future Organizational with E-procurement & Mean \\
\hline D1 & Short-term organizational performance & 3.77 \\
D2 & Long-term organizational performance & 4.37 \\
D3 & Improve cost performance in organization & 3.77 \\
D4 & Organizational competitiveness & 4.10 \\
D5 & Strategic alliance and networking & 4.07 \\
D6 & Organization achieved process effiency & 3.87 \\
D7 & Organization achieved process effectiveness & 3.93 \\
D8 & Organization's income increases after e-procurement adoption & 3.57 \\
\cline { 2 - 3 } & \multicolumn{2}{c}{ Mean all } \\
\hline
\end{tabular}

\subsection{Regression Analysis}

The results of the simultaneous $\mathrm{f}$ test are shown in table 5 . In the table, the calculated $\mathrm{f}$ value is 8.87 and the significance value is 0.00 . The known $\mathrm{f}$ value is 2.92 . Then the calculated $\mathrm{f}$ value $>$ of the table $\mathrm{f}$ value and the significance value $<0.05$. It can be concluded that the hypothesis is accepted or there is an influence of the independent variables simultaneously on the dependent variable in the regression analysis.

Table 5. Simultaneous F Test Results

\begin{tabular}{cc}
\hline $\mathrm{F}$ & Sig \\
8.87 & 0.000 \\
\hline
\end{tabular}

In table 6 the coefficient of determination is known to reach 0.506 or $50.6 \%$. This shows that the independent variable simultaneously gives an effect on the dependent variable of $50.6 \%$. For the remaining $49.4 \%$ given by the variables not included in this research.

Table 6. Results of Summary Model Processing

$\begin{array}{ccc}\mathrm{R} & R \text { Square } & \text { Adjusted } R \text { Square } \\ 0.711 & 0.506 & 0.449\end{array}$

\section{Conclusions}

a. The result of this study shows these variabels are perceive benefit of e-procurement, perceived barriers to e-procurement implementation, and critical success factors in eprocurement give significant impact to several of perceived future of e-procurement.

b. Each of these variable elements from perceive benefit of e-procurement and critical success factors in e-procurement must be present in a implementation of eprocurement. 
c. Each of these variable perceived barriers to e-procurement implementation elements from must be avoid in a implementation of e-procurement.

\section{References}

[1] Mihaly, M.: Strategic sourcing, IndustryWeek, Vol. 248 No. 4, pp. 3-5. (1999).

[2] Kluge, J.: Reducing the cost of goods sold: role of complexity, design relationships, McKinsey Quarterly, 2, 212-15. (1997).

[3] Porter, E. M.: Competitive Advantage-Creating and Sustaining SuperiorPerformance. New York : Free Press, (1985).

[4] Chase, R. and Jacobs, R.: Operations and Supply Chain Management. 14th Edition, McGraw-Hill Higher Education, New York. (2013).

[5] Zenz, G.J.: Purchasing and the Management of Materials, Wiley, New York, NY. (1994).

[6] Peraturan Presiden Republik Indonesia Nomor 54 Tahun 2010 Tentang Pengadaan Barang/Jasa Pemerintah.

[7] Muffatto, M. and Payaro, A.: Implementation of e-procurement and e-fulfillment processes: a comparison of cases in the motorcycle industry, International Journal of Production Economics, Vol. 89 No. 3, pp. 339-351. (2004).

[8] Puschmann, T. and Alt, R.: Successful use of e-procurement in supply chain, Supply Chain Management: An International Journal, Vol. 10 No. 2, pp. 122-133. (2005).

[9] Essig, M. and Arnold, U.: Electronic procurement in supply chain management: An information economics-based analysis of electronic markets, Journal of Supply Chain Management, Vol. 37 No. 3, pp. 43-49. (2001).

[10] Petersen, K.J., Odgen, J.A. and Carter, P.L.: B2B e-market places: a typology by functionality", International Journal of Physical Distribution \& Logistics Management, Vol. 37 No. 1. pp. 4-18. (2007).

[11] Roche, J.: Are you ready for E-procurement?. Strategic Finance 83 (1), 56-59. (2001).

[12] Gunasekaran, A., McGaughey, R.E., Ngai, E.W.T., Rai, B.K.: E-Procurement adoption in the Southcoast SMEs. (2009).

[13] Hawking, P., Stein, A., Wyld, D.C., Foster, S.: E-procurement: Is the ugly duckling actually a swan down under? Asia Pacific Journal of Marketing and Logistics 16 (1), 3-25. (2004).

[14] Fu, H.-P., Chang, T.-H., Wu, W.-H.: An implementation model of an E-procurement system for auto parts: a case study. Production Planning and Control 15 (7), 662-670. (2004).

[15] Attaran, M.: The coming age of E-procurement. Industrial Management \& Data Systems 101 (4), 177-181. (2001). 